\title{
The Characteristics of Turkish and Refugee Neonates and Analysis of Short-Term Outcomes
}

\author{
Sahin Hamilcikan ${ }^{1 \oplus}$, Emrah Can ${ }^{1 \oplus}$
}

\begin{abstract}
:
The characteristics of Turkish and refugee neonates and analysis of short-term outcomes

Objective: The aim was to the evaluate Turkish and refugee newborns' characteristics and analyze the results.

Material and Method: All Turkish and refugee neonates born and followed in University of Health Sciences, Bağcılar Training and Research Hospital's neonatal monitoring unit between November 2015 and October 2016 were included to the study.

Results: A total of 3109 neonates were included in the study. $62.5 \%(n=1303)$ of the Turkish newborns and $55 \%(n=559)$ of the refugee newborns were female $(p=0.0001)$. Spontaneous vaginal delivery percentage was $58.3 \%(n=1213)$ in Turkish newborns and $57.7 \%(n=591)$ in refugees $(p=0.001)$. Neonatal intensive care unit admission rates of refugee newborns were found significantly higher $(8.8 \%)$ than Turkish neonates $(p=0.004)$. There were no significant differences in birth weights, heights, head circumferences, gestational weeks and cord blood gas analysis and critical congenital heart diseases screening results were similar between the groups. Refugee mother's antenatal followup rates (38.4\%) were lower than Turkish mothers (73.8\%) ( $p<0.0001)$. Refugee neonates were more frequently diagnosed with hyperbilirubinemia that required phototherapy $(p=0.0004)$ and gestational diabetes diagnosis was detected more often in refugee mothers $(p=0.001)$.

Conclusion: Refugees and Turkish neonates are born with anthropometric similarities. However, refugee newborns are more likely to require neonatal intensive care admission because they are more diagnosed with hyperbilirubinemia requiring phototherapy and they have more frequently gestational diabetes mothers. This may be related to the low antenatal follow-up rates of refugee mothers.

Keywords: Neonatal screening, refugee neonates, Turkish neonates
\end{abstract}

ÖZET:

Türk ve mülteci yenidoğanların özellikleri ve kısa dönem sonuçlarının analizi

Amaç: Türk ve mülteci yenidoğanların özelliklerinin değerlendirilerek sonuçlarının analizi amaçlandı.

Gereç ve Yöntem: Sağlık Bilimleri Üniversitesi Bağcılar Eğitim ve Araştırma Hastanesi Yenidoğan izlem ünitesinde Kasım 2015-Ekim 2016 tarihleri arasında doğan Türk ve mülteci yenidoğanlar çalışma kapsamına alındı.

Bulgular: Çalışmaya toplam 3109 bebek dahil edildi. Türk yenidoğanların \%62.5 ( $n=1303$ )'i kız; mültecilerin \%55 ( $n=559)^{\prime} i \mathrm{kız}$ idi $(p=0.0001)$. Doğumların \%58.3'ü Türk yenidoğanlarda $(n=1213)$ normal spontan vajinal iken mülteci bebeklerde \%57.7'si $(n=591)$ normal spontan vajinal doğum ile doğmuş idi $(p=0.001)$. Yenidoğan yoğun bakıma yatış oranları sıklığı \%.8.8 olarak mülteci bebeklerde Türk bebeklere göre anlamlı olarak yüksek idi $(p=0.004)$. Türk ve mülteci yenidoğanlar için, doğum tartısı, boyu, baş çevresi, gebelik haftası ve kordon kan gazı değerleri arasında anlamlı fark saptanmadı (p>0.05). Kritik konjenital kalp hastalığı taraması açısından gruplar arasında fark tespit edilmedi. Mülteci annelerde antenatal takip oranları (\%38.4) Türk annelere göre (\%73.8) düşük düzeyde tespit edildi ( $p<0.0001)$. Mülteci yenidoğanların daha fazla gebelik diyabetli anne bebeği ve fototerapi gerektiren hiperbilirubinemi tanısı aldıkları tespit edildi $(p=0.0001$ ve $p=0.004)$.

Sonuç: Mülteci ve Türk yenidoğanların antropometrik olarak benzer özellikler ile doğmaktadır. Ancak mülteci yenidoğanlar daha sık gebelik diyabetli anne bebeği ve fototerapi gerektiren hiperbilirubinemi tanısı alarak yenidoğan yoğun bakım gereksinimi duymaktadır. Bu durum mülteci annelerin düşük antenatal takip oranı ile ilişkili olabilir.

Anahtar kelimeler: Yenidoğan izlemi, mülteci yenidoğan, Türk yenidoğan

Ş.E.E.A.H. Tıp Bülteni 2017;51(4):293-7
Bagcilar Training and Research Hospital Department of Neonatology, Istanbul - Turkey

Address reprint requests to / Yazışma Adresi: Emrah Can,

Bagcilar Training and Research Hospital, Department of Neonatology, Istanbul - Turkey

E-mail / E-posta: canemrahcan@yahoo.com

Date of receipt / Geliş tarihi: June 7, 2017 / 7 Haziran 2017

Date of acceptance / Kabul tarihi: August 9, 2017 / 9 Ağustos 2017 


\section{INTRODUCTION}

Newborn monitoring units are the units where routine care of newborn babies is made in hospitals in general and triages are performed according to their required care levels. These units are the units where postnatal adaptation period is passed, resuscitation is performed when necessary, the primary evaluations and follow-up of home-born babies are performed, routine anthropometric measurements, vitamin $\mathrm{K}$ and hepatitis $\mathrm{B}$ vaccination are performed. Today, the first hour after birth; even minutes have become more important in the newborn practice and the establishment of qualified newborn monitoring units has resulted in a significant decrease in the mortality and morbidity rates of infants (1).

Refugee mothers and their babies live various health problems all over the world. These problems affect primarily the mother in the antenatal period, then the delivery process, and then the newborns in the postnatal period. Unintended pregnancies, highrisk pregnancies, abortus and birth complications, birth trauma, anemia, small for gestational age (SGA) newborns and neonatal sepsis are accepted as the main causes of these problems $(2,3)$.

With this study it was aimed to evaluate the characteristics of Turkish and refugee newborns in our hospital's newborn monitoring unit and to analyze the results.

\section{MATERIAL AND METHOD}

The study was conducted between November 2015 and October 2016 with Turkish and refugee newborns born and followed up at University of Helath Sciences, Bağcılar Training and Research Hospital, newborn monitoring unit.

Neonates who were born and/or referred to the hospital, including births at home were included in the study. Information on infants' mothers was obtained from their files and their anamnesis. The gestational weeks, follow-up status and the presence of diseases detected during the antenatal period of the mothers were questioned. Necessary information on the delivery type, cord blood gas, head circumference, birth height and birth weight, gender, preductal and postductal oxygen saturations, newborn intensive care unit requirements in the postnatal period were recorded. Lactation consultancy was provided for all infants during follow-up and routine hepatitis $B$ vaccination and vitamin $K$ were administered as $1 \mathrm{mg}$ IM. The hospital's ethics committee approved the study. Verbal approvals were obtained from the families of the babies participating in the study.

In the study, t-test, chi-square and Fisher's exact test were used to compare qualitative and quantitative data, as well as descriptive statistical methods (mean, standard deviation, median, upper and lower limit). Significance was assessed at $\mathrm{p}<0.05$ level.

\section{RESULTS}

A total of 3109 infants were included in the study. $66.9 \%(n=2083)$ of the infants were term, $31 \%$ $(n=964)$ were preterm and $2 \%(n=62)$ were postterm. The SGA infant rate was $2.9 \%(n=93) .62 .5 \%$ of

\section{Table-1: Birth related features}

\begin{tabular}{|c|c|c|c|}
\hline & $\begin{array}{c}\text { Turkish newborn } \\
\text { (n: 2083) } \\
n(\%)\end{array}$ & $\begin{array}{c}\text { Refugee newborn } \\
\text { (n: 1026) } \\
n(\%)\end{array}$ & $\mathbf{P}$ \\
\hline \multicolumn{4}{|l|}{ Gender } \\
\hline Female & $1303(62.5)$ & $559(55)$ & 0.0001 \\
\hline Male & $780(37.5)$ & $467(45)$ & \\
\hline \multicolumn{4}{|l|}{ Birth type } \\
\hline Normal spontaneous vaginal & $1213(58.3)$ & $591(57.7)$ & 0.001 \\
\hline C-section & $870(41.7)$ & $435(42.3)$ & \\
\hline Antenatal follow-up & $1538(73.8)$ & $394(38.4)$ & 0.0001 \\
\hline \multicolumn{4}{|l|}{ Monitoring outcomes } \\
\hline Discharged & 1958 (93.9) & $936(91.2)$ & 0.56 \\
\hline Hospitalization at intensive care & $125(6.1)$ & $90(8.8)$ & 0.004 \\
\hline
\end{tabular}


Turkish newborns ( $\mathrm{n}=1303)$, and $55 \%$ of refugees $(n=559)$ were female $(p=0.0001) .58 .3 \%(n=1213)$ of Turkish newborns and $57.7 \%(n=591)$ of the refugee newborns were found to be born via normal spontaneous vaginal delivery $(p=0.001)$. The rate of hospitalization in newborn intensive care unit was significantly higher in refugee infants $(p=0.004)$ (Table-1).

General characteristics for Turkish and refugee newborns are presented in Table-2. There was no significant difference in birth weight, height, head circumference, gestational week and cord blood gas values between the two groups. There was no difference between the groups in terms of critical congenital heart disease screening. Antenatal follow-up rates were lower in refugee mothers $(38.4 \%)$ than in Turkish mothers $(73.8 \%)(p<0.0001)$ (Table-2).

It was found that refugee newborns were diagnosed as baby with a mother with gestational diabetes and hyperbilirubinemia that requires phototherapy at higher rates $(p=0.0001$ and $p=0.004)$. There was no significant difference between the two groups in terms of premature rupture of membranes, presence of meconium in amniotic fluid, Down syndrome, respiratory distress, goitre in mother, epilepsy in mother, maternal psychosis, polycythemia, meningomyelocele, suspicion of early sepsis, surgical pathologies and prematurity (Table-3).

Table-2:General characteristics of newborns

\begin{tabular}{|c|c|c|c|}
\hline & $\begin{array}{c}\text { Turkish newborn } \\
\text { (n: 2083) } \\
\text { Mean } \pm \text { SD* }\end{array}$ & $\begin{array}{c}\text { Refugee newborn } \\
\text { (n: 1026) } \\
\text { Mean } \pm \text { SD }\end{array}$ & $\mathbf{P}$ \\
\hline Birth weight (g) & $3261.30 \pm 424.50$ & $3332.40 \pm 365.70$ & 0.56 \\
\hline Height $(\mathrm{cm})$ & $50.11 \pm 2.05$ & $50.06 \pm 1.69$ & 0.76 \\
\hline Head circumstance $(\mathrm{cm})$ & $34.78 \pm 1.36$ & $34.48 \pm 1.01$ & 0.45 \\
\hline Gestational week & $38.07 \pm 1.22$ & $38.21 \pm 1.61$ & 0.71 \\
\hline Preductal SpO2 & $96.79 \pm 0.89$ & $97.06 \pm 0.93$ & 0.68 \\
\hline Postductal SpO2 & $97.40 \pm 0.87$ & $97.45 \pm 0.83$ & 0.42 \\
\hline \multicolumn{4}{|l|}{ Cord blood gas } \\
\hline $\mathrm{pH}$ & $7.29 \pm 0.08$ & $7.31 \pm 0.06$ & 0.31 \\
\hline $\mathrm{HCO} 3$ & $22.65 \pm 2.03$ & $22.20 \pm 2.20$ & 0.28 \\
\hline $\mathrm{PCO} 2$ & $49.26 \pm 13.37$ & $44.88 \pm 9.75$ & 0.58 \\
\hline Base gap & $-4.20 \pm 1.83$ & $-4.03 \pm 1.58$ & 0.74 \\
\hline
\end{tabular}

*mean \pm standard deviation

Table-3: Clinical features of mothers and newborns

\begin{tabular}{|c|c|c|c|}
\hline & $\begin{array}{c}\text { Turkish newborn } \\
\text { (n: 2083) } \\
n(\%)\end{array}$ & $\begin{array}{c}\text { Refugee newborn } \\
\text { (n: 1026) } \\
n(\%)\end{array}$ & $\mathbf{P}$ \\
\hline EMR (>18 hours) & $330(15.8)$ & $146(14.2)$ & 0.35 \\
\hline Meconium in amniotic fluid & $88(4.2)$ & $95(9.2)$ & 0.25 \\
\hline Down Syndrome & $3(0.1)$ & $2(0.1)$ & 0.21 \\
\hline Respiratory distress & $62(2.9)$ & $38(3.7)$ & 0.44 \\
\hline Gestational Diabetes & $108(5.1)$ & $99(9.6)$ & 0.0001 \\
\hline Maternal goitre & $3(0.1)$ & $2(0.1)$ & 0.18 \\
\hline Hyperbilirubinemia & $10(0.48)$ & $15(1.4)$ & 0.004 \\
\hline Maternal epilepsy & $3(0.1)$ & - & - \\
\hline Maternal psychosis & $1(0.01)$ & - & - \\
\hline Polycythemia & $27(0.1)$ & $12(1.1)$ & 0.36 \\
\hline Prematurity (<37 wks) & 374 (17.9) & $271(26.4)$ & 0.19 \\
\hline Meningomyelocoele & $5(0.02)$ & $4(0.3)$ & 0.56 \\
\hline Suspicion of early sepsis & $26(11.2)$ & $12(12.1)$ & 0.22 \\
\hline Surgical pathologies & $5(0.02)$ & $3(0.02)$ & 0.47 \\
\hline
\end{tabular}




\section{DISCUSSION}

In our country, especially the children brought by the refugees in recent years, and also the babies born as a result of the pregnancies they have experienced in our country, cause new demographic features in newborn and child health area. This is particularly noticeable in large cities, especially those with high immigration rates. In our study, refugee babies born in our unit were detected as 33\% and Turkish citizens as $67 \%$. In a study conducted in our country, the rate of refugee birth was found to be $1.2 \%$ (4). The birth rates of refugees is high, as our hospital is in the region where they live intensely.

In our country, pregnancy follow-up files are kept in family health centers and pregnant women and infants are evaluated in total 4 control periods, including the first trimester and the last period of pregnancy (5). In our unit, it was found that the follow-up rate of refugee pregnancies was significantly lower in the antenatal period. It is thought that this may be related to reasons such as refugee pregnancies being followed at different period of times, not applying for follow-up, or refugee mothers not having enough information on this issue.

According to the Turkey Demographic and Health Survey (TDHS) 2013 data, the cesarean delivery rate in our country is $48 \%$. In our study, it was determined that Turkish babies were born with normal spontaneous vaginal delivery and refugee babies were born with more cesarean delivery. This situation suggests that the refugee mothers who are not under any follow-up give birth under emergency conditions with cesarean delivery, due to negative conditions detected at admission. However, in our study, in terms of gestational weeks, we found that there was no difference between Turkish and refugee babies.

A significant proportion of the infants who are admitted to the newborn units are SGA babies according to their gestational week and their incidence is reported as $3-7 \%(6)$. The rate of SGA infants in our unit was found to be $2.9 \%(n=93)$ and this ratio was found to be similar between Turkish and refugee infants.

In the first examination in the delivery room, measurements of height, weight and head circumference and their evaluation according to the percentile curves, as well as the vital signs of the baby are included (7). In our unit, anthropometric measurements taken after delivery of babies did not reveal any difference for weight, height, head circumference between Turkish and refugee newborns. It was thought that the insignificant difference between the gestational weeks of the infants and the birth weight, head circumference and height may show that the environmental factors alone were not effective in neonatal growth and development.

The American Academy of Pediatrics (AAP) Committee on Fetus and Newborn recommends taking umbilical cord blood samples and evaluating the blood gas for asphyxia in the case where the $5^{\text {th }}$ minute Apgar is $\leq 5$ (8). There was no significant difference between the Turkish and refugee newborns in terms of cord blood gas values.

The AAP recommends that all newborns have the critical congenital heart disease scanning test after completing the first 24 hours. It is aimed to diagnose newborns with critical congenital heart disease in early period by this test. The protocol for this is based on the principle of monitoring the preductal and postductal oxygen saturations with the pulse oximetry device (9). In our study, there was no difference between Turkish and refugee newborns with the screening of critical congenital heart disease routinely performed on newborns in our unit.

Following physical examinations and laboratory tests with taking the antenatal risk conditions of infants into account in the newborn monitoring units, decisions such as a short follow-up period, admission to the newborn intensive care, or giving the baby to the mother are made. All newborns undergoing basic care services are then guided according to these monitoring principles. In a study, there was no increase in perinatal pathology despite poor antenatal care in refugees (10). In another study, it is stated that the refugees in different centers have poor perinatal outcomes (11). In our study, it was found that the refugee babies had been more admitted to the neeonatal intensive care unit. It was thought that this might be associated to the refugee mothers to have 
irregular or no antenatal follow-up. According to clinical features; follow-up and admission of patients were performed for reasons such as early membrane rupture, respiratory distress, meconium in amniotic fluid, preterm delivery, suspicion of early sepsis and polycythemia.

When the risk factors for neonates for admission to neonatal intensive care unit were assessed, refugee newborns were found to be more the children of women with gestational diabetes and to have hyperbilirubinemia requiring treatment. This situation

\section{REFERENCES}

1. Temel yenidoğan bakımı. T.C. Sağlık Bakanlığı Türkiye Halk Sağlığı Kurumu, Ankara, 2015. p.10.

2. Eskiocak M. Suriye iç Savaşının Hatay Iline Etkileri. Türk Tabipleri Birliği, Ankara, 2013; 1: 50-63.

3. Karadağ Ö ve Altıntaş KH. Mülteciler ve Sağlık. TAF Preventive Medicine Bulletin 2010; 9: 55-62.

4. Büyüktiryaki M, Canpolat FE, Alyamaç Dizdar E, Okur N, Kadıoğlu Şimşek G. Neonatal outcomes of Syrian refugees delivered in a tertiary hospital in Ankara, Turkey. Confl Health 2015; 9: 38.

5. Türkiye Halk Sağlığı Kurumu. Gebe izlemleri. http://ailehekimligi. gov.tr/ana-cocuk-sal/gebelik/297-gebe-zlemleri.html Erişim tarihi: 7 Haziran 2017.

6. Teranishi H, Nakagava H, MarmotM. Socialclassdifference in catchupgrowth in a national British cohort. Arch Dis Child 2001; 84: 218-21. [CrossRef]

7. World Health Organization (WHO). WHO recommendations on postnatal care of the mother and newborn. Geneva (Switzerland): World Health Organization (WHO); 2013: 62. can be explained by the fact that the Turkish citizen pregnancy follow-ups to be more frequent and having the necessary screening tests and in the neonatal period, they bring their babies in time for control follow-ups.

As a result, rate of newborns and their admission to the hospital increase due to the increase in the number of refugees. Improving antenatal care rates can contribute to reducing hospital admissions for refugees and may help reducing mortality and morbidity rates for these infants.

8. American Academy of Pediatrics Committee on Fetus and Newborn, American College of Obstetricians and Gynecologists Committee on Obstetric Practice. The Apgar Score. Pediatrics 2015; 136: 819-22. [CrossRef]

9. Mahle WT, Martin GR, Beekman RH 3rd, Morrow WR; Section on Cardiology and Cardiac Surgery Executive Committee. Endorsement of Healthand Human Services recommendation for pulse oximetry screening for critical congenital heart disease. Pediatrics 2012; 129:1 90-2.

10. Erenel H, Aydogan Mathyk B, Sal V, Ayhan I, Karatas S, KoC Bebek A. Clinical Characteristics and pregnancy outcomes of Syrian refugees: a case-control study in a tertiary care hospital in Istanbul, Turkey. Arch Gynecol Obstet 2017; 295: 45-50. [CrossRef]

11. Michaan N, Gil Y, Amzalag S, Laskov I, Lessing J, Many A. Perinatal outcome and financial impact of Eritrean and Sudanese refugees delivered in a tertiary hospital in Tel Aviv, Israel. Isr Med Assoc J 2014; 16: 371-4. 